\title{
EXPLORING THE USE OF MODAL AUXILIARY VERBS IN CORPUS OF CONTEMPORARY OF AMERICAN ENGLISH (COCA)
}

\author{
Meita Lukitawati Sujatna ${ }^{1}$, Eva Tuckyta Sari Sujatna ${ }^{2}$ dan Kasno Pamungkas ${ }^{2}$ \\ ${ }^{1}$ Department of English, Faculty of Language, Universitas Widyatama \\ ${ }^{2}$ Department of Linguistics, Faculty of Cultural Sciences, Universitas Padjadjaran \\ E-mail: sujatna.meita@widyatama.ac.id
}

\begin{abstract}
This paper deals with the frequent use of modal auxiliary verbs in Corpus of Contemporary of American English (COCA). The modal auxiliary verbs mentioned as the data are can, could, will, would, may, might, shall, should, and must. Each data collected are taken from COCA in https://corpus.byu.edu/cocal. The research method is descriptive analysis; the present writers describe every data related to their function in each clause. The findings are related to the highest frequency and the number of elements follow the modal auxiliary verbs. From the 6,008,840 data, it is found the verb would (1,301,269 data) is the most frequently used, it is followed by the verb can (1,228,608 data), the verb will (1,118,515 data), the verb could (885,835 data), the verb may (494,144 data), the verb should (435,903 data), the verb might (300,258 data), the verb must (223,936 data), and the verb shall (20,372 data). This study has also revealed the number of elements following each of modal auxiliary verbs found in the COCA. It is reported that the verb would has seven different types, will has five different types, could and should has four different types, can, may, must, and shall have three different types, and might has two different types as the least number of elements following the verb. From the data analyzed, it is also reported that the modal auxiliary verb would is not only has the highest number in data (as the highest frequency) but also has various number of elements follow the verb.
\end{abstract}

Keywords: modal auxiliary verb; corpus; Corpus of Contemporary American English; central modals

\section{MENEROKA PENGGUNAAN VERBA BANTU MODAL DALAM CORPUS OF CONTEMPORARY OF AMERICAN ENGLISH (COCA)}

\begin{abstract}
ABSTRAK. Tulisan ini mengenai frekwensi penggunaan verba bantu modal pada Corpus of Contemporary of American English (COCA). Verba bantu modal yang digunakan sebagai data adalah can, could, will, would, may, might, shall, should, dan must. Setiap data yang digunakan, dikumpulkan dari pada COCA dalam https://corpus.byu.edu/coca/. Metode penelitian yang digunakan di dalam riset ini adalah metode deskriptif; para peneliti menggambarkan setiap data yang berhubungan dengan fungsi pada setiap klausa. Hasil penelitian menunjukkan frekwensi tertinggi dan jumlah elemen yang mengikuti verba bantu modal. Dari 6.008.840 data, ditemukan verba would (1,301,269 data) sebagai verba bantu yang paling sering digunakan, diikuti oleh verba can (1,228,608 data), verba will (1,118,515 data), verba could (885,835 data), verba may (494,144 data), verba should (435,903 data), verba might (300,258 data), verba must (223,936 data), danverbashall (20,372 data). Hasil penelitian ini juga menunjukkan jumlah elemen yang mengikuti masing masing verba bantu yang ditemukan di dalam COCA. Dilaporkan juga verba would memiliki tujuh tipe elemen yang berbeda, verba will memiliki lima tipe yang berbeda, verba could dan should memiliki empat tipe yang berbeda, verba can, may must, dan shall memiliki tiga tipe yang berbeda, dan verba might memiliki dua tipe yang berbeda sebagai jumlah elemen yang paling sedikit yang mengikuti kesembilan verba tersebut. Berdasarkan analisis data, dilaporkan bahwa verba bantu would bukan hanya memiliki jumlah data yang paling banyak(frekwensi yang paling tinggi), tetapi juga memiliki variasi jumlah elemen yang mengikuti verba tersebut yang paling banyak.
\end{abstract}

Kata kunci: verba bantu modal; korpus; Corpus of Contemporary American English; central modals;

\section{INTRODUCTION}

Many researchers do their research on Linguistics in most languages including English. It is limited research on specific Linguistic topic such as verb, especially, in modal auxiliary verbs. It is reported that Verstraete (2001), Hsieh (2005), and Mukundan \& Khojasteh (2011) did their research on modal auxiliary verbs. Verstraete's research discusses the system of Modal Auxiliary in English. He concerned the difference of subjective and objective modality on English modal auxiliaries. Hsieh did his research on Chinese language concerning modal verbs and modal adverbs based on Semantic source. Mukundan \& Khojasteh's research is on Malaysian
English textbooks concerning modal auxiliary verbs. They found that the distinctions ofEnglish language textbooks and real language use. Besides the three previous research mentioned, Kennedy (2002) did his research related to British National Corpus (BNC) as the source of the classification of modal verbs. He did his research to identify the distribution of modal verbs in it. He offered nine different types of pattern consisting modal verbs and he argued that the nine different patterns found in British National Corpusrelated to 14 different types of modal verbs. Further he concluded that the modal verb will accounts for almost $23 \%$ of all modal tokens, followed by would, can, and could. It is found thatthe modal verbcan frequently found in spoken texts. 
From the previous research described, many researchers do their research related on modal auxiliary verbs, but it is only one research on the frequent use of modal auxiliary verbs in English, especially in British National Corpus (BNC). This paper is a preliminary research, and the aims of the research are to describe the frequency and the order of the rank of modal auxiliary verbs found in the COCA and to describe the elements following each modal auxiliary verbs found in the COCA.

Based on the two aims of the research mentioned, the present writers collected and identifiedthe data taken from the COCA in https://corpus.byu.edu/coca/. The data taken are limited on modal auxiliary verbs; they are can, could, will, would, may, might, shall, should, and must later called central modals. In Quirk et al. (1992), followed by Biber et al. (1999) and also mentioned by Kennedy (2002) that the 'central' modals are considered to be will, would, can, could, may, might, shall, should, and must or sometimes called as auxiliary modals. In line with Quirk et al. (1992), Kennedy (2002) mentioned in the nine central modals is found a small group of 'marginal modals'. The marginal modals areought to, need to, used to and dare which can act like modals and sometimes seem like main verbs. There is another group of expression known as 'semi-modals', which function like modals - (had) better, (have) got to, be about to, be going to, and be supposed to. This present paper only focuses on the nine 'central modals': will, would, can, could, may, might, shall, should, and must, and excludes both 'marginal modals' and 'semi-modals'.

\section{RESEARCH METHOD}

The research method applied in this research is descriptiveanalysis. The corpus that is referred as the dataare obtained from COCA. It is reported in https://corpus.byu. edu/coca/ that this COCA corpushasabout 560 million wordsof text and 20 million words whichwere collected from the year 1990-2017. The corpus aredivided into spoken, popular magazines, newspaper, fiction, and academic texts.

The data obtained in this present paper are limited on the clauses containing modal auxiliary verbs and every data collected is described one by one. The each data has different function from one to another, since it has different structure of each.

The modal auxiliary verbs used in this research are nine modal auxiliary verbs which categorized into 'central modals' as keywords. The nine keywords as the modal auxiliary verbs (will, would, can, could, may, might, shall, should, and must)are inputted one by one to application of COCA in https://corpus.byu.edu/coca/.

Jones \& Walter (2015) offered the definition of corpus, they argued that corpus are searchable collection of texts electronically stored while the text could be spoken or written in various length, although generally, it would be longer than a single utterance or a single written clause. The corpus could be measured by the number of words or the number of tokens found in every utterance or written clause.

After collecting the data from COCA, the present writers identified $6,008,840$ corpus one by one to classify the types of verbs and the element following the verb. Every keyword, as one of modal auxiliary verbs, is identified of each function in each clause. Then the collected corpus are presented as the data of the present research. After identifying, analyzing, and describing the data, the present writers counted and compared the frequent use of the modal auxiliary verbs in COCA. Then the present writers described each function of every keyword and describe the element following the verb.

\section{RESULT AND DISCUSSION}

\section{English Modal Auxiliary Verb}

Verb is the important parts in some languages including English. In the English clause, it always has a verb since the verb is the main part of clause. So that, every clause in English has, at least, one verb. The one verb in a clause is called main verb (sometimes called full verb or lexical verb) while the two verbs or more could be a main verb and the othersare auxiliary verb(s). The auxiliary verb could be modals auxiliary verbs and primary verbs or sometimes called as semi auxiliary verbs as described by Quirk et al. (1992) that verbs is one of the class of words. Related to the function of each, the verbs could be classified into three different major categories. The three categories are named full verbs or is known as lexical verbs, the second one is primary verbs, and the last is modal auxiliary verbs. The full verbs or lexical verbs in English are such as buy, make, and go while the primary verbs are be, have, and do (the three verbs could be full verbs as be in They are singers, have in They have a car, and $d o$ in They do it). The modal auxiliary verbs as the focus of the present research are will, would, shall, should, can, could, may, might, and must.

To understand the definition deeper, in line with Sujatna (2012) who described the classification of the verbs above in the following Picture 1.

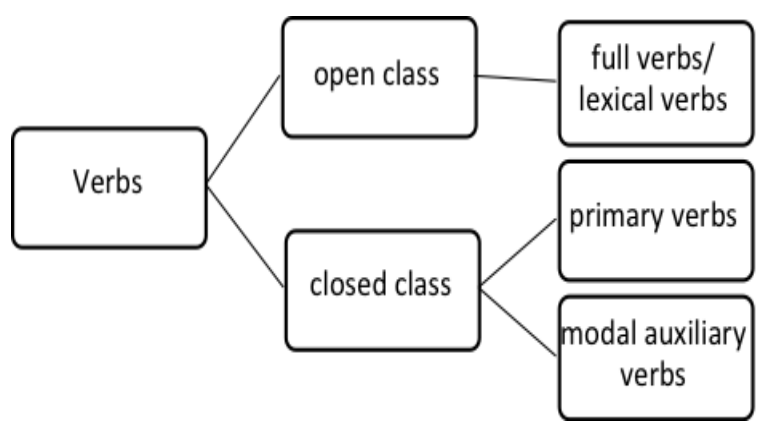

Picture 1. Verbs Classification

Exploring the use of Modal Auxiliary Verbs in Corpus of Contemporary of American English (COCA)

(Meita Lukitawati Sujatna, Eva Tuckyta Sari Sujatna, dan Kasno Pamungkas) 
Kennedy (2002) argued that verbs constitute about 20 per cent are in written texts and about 8 per cent of all verb forms are typically constitute modal verbs. Modal auxiliary verbs have the important role in clauses, including English clauses, in line with Manaf (2007) in Mukundan \& Khojasteh (2011). Mukundan \& Khojasteh (2011) reported that Manaf (2007) argued that one of the important part of grammar and semantics of most languages including English is modal auxiliary verbs. He added that modal auxiliary verbs contribute to the semantics communication.

To understand more about modal auxiliary verbs, the present writers describe the characteristics of modal auxiliary verbs as argued by (Watkins, 1990); (1) go before not in negative sentence (e.g. He would not come.), (2) go before the subject in interrogative sentences (e.g. May I go home?), (3) go before forms of be and have in compound tenses (e.g. He may be coming or He may have come), and (4) do not have Infinitive or Gerund forms (we cannot say to must or *mighting).

Mukundan \& Khojasteh (2011) in line with Biber et al. (1999) explained that some particular modal verbs show dissimilarity for their combinations since the majority of modal verbs take place with marked voice or aspect. They also reported that the modal auxiliary verbs can, could, should, and must are commonly found in passive construction while may, might, should, and must are the most commonly used modal with perfect aspect construction.

Besides Biber et al. (1999) and Mukundan \& Khojasteh (2011) who reported the usage of modal auxiliary verbs, the following Table 1 is the modal verb phrase structure mentioned by Kennedy (2002) in British National Corpus (BNC).

Modal auxiliary verbs have own function of each modal in every sentence, in this paper, English sentences as Biber et al. (1999) mentioned that according to their meaning modals and semi-modals could be classified into three different major categories. The modal auxiliary verbs can, could, may, and might express permission/ possibility/ ability while the modal auxiliary verbs must and should express obligation/ necessity, and modal auxiliary verbs will, would, and shall express volition/ prediction.

\section{Distribution of Modal Auxiliary Verbs in the COCA}

Modal auxiliary verbs discussed in this present paper is 'central' modals; they are nine central modal verbs. The central modal verbs are will, would, can, could, may, might, shall, should, and must. From the collected data, totally the present writers found 6,008,840 data. The examples of the data are described in the following.

if they had not brought the harmful result that would otherwise subject them to heightened punishment \# INTRODUCTION \# In 2019, three

and completed crimes are already punished equally, our recommendation would therefore not have any effect on how such offenders are punished. \# But

how such offenders are punished. \# But our proposal would have far more dramatic implications with regard to the punishment of non-intentional offenses.

non-intentional offenses as abandoning a regime of differential punishment would almost always lead to a significant reduction in punishment for offenders of nonintentional crimes

Picture2. The usage of modal auxiliary modal in COCA

From the total number mentioned, the following is a description of the distribution of the nine modal auxiliary verbs in COCA as represented in the following Picture 3.

Table 1. The Usage of Modal Auxiliary Verbs

\begin{tabular}{|c|c|c|}
\hline No & Types of Modal Auxiliary Verb & Modal in Clauses \\
\hline 1 & Modal alone & Who will do? I will. \\
\hline 2 & Modal + V-infinitive & Sam can sing. \\
\hline & & She must be angry. \\
\hline & & You should have gone. \\
\hline 3 & $\begin{array}{l}\text { Modal }+ \text { V-be }+ \text { Past Participle } \\
\text { (Modal with Passive) }\end{array}$ & It should be done. \\
\hline 4 & $\begin{array}{l}\text { Modal }+ \text { V-be }+ \text { present participle } \\
\text { (Modal with Progressive Aspect) }\end{array}$ & They will be arriving soon. \\
\hline 5 & $\begin{array}{l}\text { Modal }+ \text { V-have }+ \text { past participle } \\
\text { (Modal with Perfect Aspect) }\end{array}$ & $\begin{array}{l}\text { He might have gone. } \\
\text { You must have been hungry. }\end{array}$ \\
\hline 6 & $\begin{array}{l}\text { Modal }+ \text { V-be }+ \text { being }+ \text { past participle (or adjective) } \\
\text { (Modal with perfect and Progressive Aspect) } \\
\text { Modal + have }+ \text { been }+ \text { past participle }\end{array}$ & $\begin{array}{l}\text { It might be being sold tomorrow. } \\
\text { He could be being disturbed. }\end{array}$ \\
\hline 7 & $\begin{array}{l}\text { (Modal with Passive and Perfect Aspect) } \\
\text { Modal + have }+ \text { been }+ \text { present participle }\end{array}$ & It should have been written. \\
\hline 8 & $\begin{array}{l}\text { (Modal with Perfect and Progressive Aspect) } \\
\text { Modal }+ \text { have }+ \text { been }+ \text { being }+ \text { past participle (or adjective) }\end{array}$ & He must have been lying. \\
\hline 9 & (Modal with Passive and Perfect and Progressive Aspect) & $\begin{array}{l}\text { He might have been being blackmailed. } \\
\text { They must have been being careless. }\end{array}$ \\
\hline
\end{tabular}




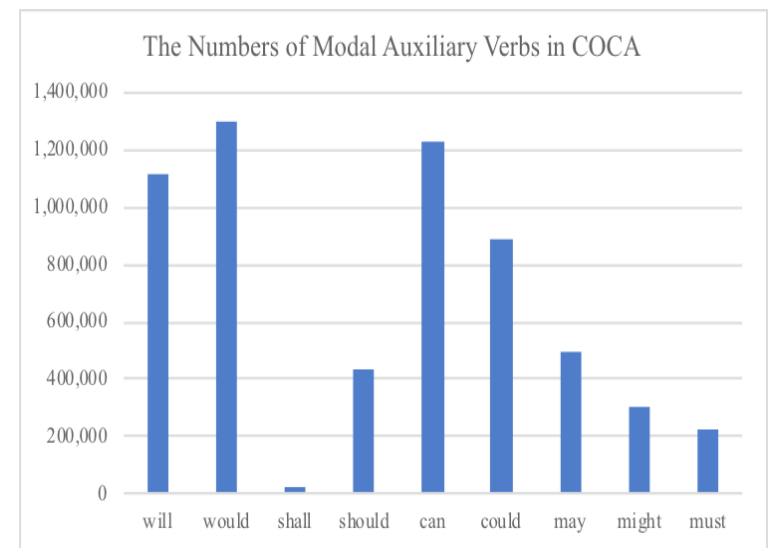

Picture 3. The Number of Modal Auxiliary Verbs in COCA

\section{(i) Modal Auxiliary Verb: would}

Verb would is also one of the modal auxiliary verbs and it is reported that it is the most frequent use in COCA. From the data collected, it is found 1,301,269 data from the total $6,008,860$ data. The present writers figure out the elements follow the verb would as described in the following.

would

... believe that an offender " deserves more punishment for having killed

a victim than he would if he had unsuccessfully tried to kill that victim “;

would $+\mathrm{V} \quad$..., but would attempt it again if the punishment for the two crimes was the same.

would + adverb $+\mathrm{V}$ \# Applying our theory would significantly reduce the severity of many offenders' punishments, helping to combat the problem

would + not $+\mathrm{V}$ Significantly, this reduction inpunishment would not come at the cost of any of the offender-facing justifications for punishment-

would + not $+\quad \ldots$ in the metaphysical sense would not $\mathrm{Adv}+\mathrm{V} \quad$ merely amount to widespread “ secondary victimizations. "However, even if one

would + PP

... the punishment of non-intentional crimes than it would for intentional offenses. This is because the difference in punishment between completed intentional offenses

would + NP Why would Microsoft support any of this, right?

It is shown from the examples above that the modal auxiliary verb would has seven different types of elements following the verbwould. Generally, the types of elements could be identified as the statement and negative forms. The statements, firstly, would only (there is ellipsis process); secondly, would $+V$ (full verb or lexical verb); thirdly, would $+A d v+V$ (full verb or lexical verb); fourthly, would + PP (Prepositional Phrase); and lastly, would +

$N P$ (Noun Phrase) while the negative forms, firstly, would $+n o t+V$ (full verb or lexical verb) and secondly, would $+n o t+A d v+V$ (full verb or lexical verb).

\section{(ii) Modal Auxiliary Verb: can}

Verb can as one of the nine modal auxiliary verbs found in the data as the second frequent use in COCA. The number of the verb can usage is 1,228,608 data taken from the $6,008,860$ data as the total number of data found in COCA. The following are the examples of the data containing modal auxiliary verb can and the elements follow the verbcan.

$$
\text { can }+\mathrm{V}
$$

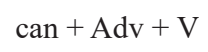
provide adequate justification for the practice of differential punishment.

The examples of the data cointaining modal auxiliary verb can above shows that the verb can only has three different types of elements. The types generally divided into two types; the statement $c a n+V$ (full verb or lexical verb) and $c a n+A d v+V$ (full verb or lexical verb); and the other is negative can + not $+V$ (full verb or lexical verb).

\section{(iii) Modal Auxiliary Verb: will}

Verb will is one of the nine of modal auxiliary verbs. This verb is the third frequent use in COCA. The number of the verb will usage is $1,118,515$ data from $6,008,860$ as the total number of data. The following are the examples of the data cointaining modal auxiliary verb will and the elements follow the verbwill.

$$
\begin{array}{ll}
\text { will }+\mathrm{V} & \text { \#However, we will show that victim- } \\
& \text { facing justifications for punishment } \\
& \text { are not available for every instance } \\
& \text { of criminal misconduct.... }
\end{array}
$$

will + not $+\mathrm{V}$ It assumes offenders are optimistic, which would imply that nonintentional offenders envision that they will not cause any harm, and would thus look primarily to the penalty for the....

will $+\mathrm{Adv}+\mathrm{V} \quad$ Indeed, non-intentional offenders will generally be worse off by virtue of having caused an unintended harmful result- i.e.,.... 
will + not + Adv + V ... the Model Penal Code (" MPC "), which stated: \# Juries will not lightly find convictions that will lead to the severest types of sentences unless the....

will + PP

... at 1589 ("It is statistically inevitable that those who have caused harm will on the average have created higher risks, in terms of circumstances of which they....

It is shown from the examples above that the modal auxiliary verb will has five different types of elements following the verbwill. Generally, the types of elements could be identified as the statement and negative forms. The first category has three types: will $+V$ (full verb or lexical verb); will $+A d v+V$ (full verb or lexical verb); and will $+P P$ (Prepositional Phrase) while the second category has two types: will + not $+V$ (full verb or lexical verb) and will $+n o t+A d v+V$ (full verb or lexical verb).

\section{(iv) Modal Auxiliary Verb: could}

Verb could is also one of the modal auxiliary verbs and the present writers found that it is the fourthmodal verb frequent use in COCA. From the data collected, the number is 885,835 data from the total $6,008,860$. The present writers figure out the elements follow the verb could as described in the following.

could ...more than ten times the number that a force of 2,500 Second World War fighter-bombers could"). \# 25. Id. at 441 (describing the " speed....

could $+\mathrm{V} \quad$...punished at all, a man considering committing a crime, such as murder, could rest assured that either ....

could $+\mathrm{Adv}+\mathrm{V}$...clearly articulating such views, crimes for which society is taken to be the victim could also include (1) particularly heinous offenses, such that the " public at....

could + not $+\mathrm{V}$ That is, if Ray's bullet had not killed Dr. King, he could not have been convicted of murder, no matter how evil his intentions; alternatively....

From the examples above, it is described that there are four types of the elements following the verbcould. The category is divided into two general types: statement and negative form. The statement are, firstly, the verb could only since there is an ellipsis process; secondly, could $+V$ (full verb or lexical verb); thirdly, could $+A d v$ $+V$ (full verb or lexical verb) while the negative form is could + not $+V$ (full verb or lexical verb).

\section{(v) Modal Auxiliary Verb: may}

Verb may is one of the nine of modal auxiliary verbs. This verb is the fifth frequent use in COCA. The number of the verb may usage is 494,144data from 6,008,860 as the total number of data. The following are the examples of the data cointaining modal auxiliary verb may and the elements follow the verb.

$$
\begin{aligned}
& \text { may }+\mathrm{V} \quad \text {... resentments caused by the infliction } \\
& \text { of important injuries have been aroused. } \\
& \text { Whatever abstract logic may suggest, } \\
& \text { a prudent legislator cannot disregard } \\
& \text { these facts of life.... } \\
& \text { may }+\mathrm{adv}+\mathrm{V} \quad \text {...am driving down the road at a } \\
& \text { reasonable speed while exercising }
\end{aligned}
$$

The examples above describes that all the data found are in the statement forms. There are three different types of elements following the modal auxiliary verb may. They are: $m a y+V$ (full verb or lexical verb); may $+A d v+V$ (full verb or lexical verb); and may $+P P$ (Prepositional Phrase).

\section{(vi) Modal Auxiliary Verb: should}

Verb should is also one of the modal auxiliary verbs and it is the sixth frequent use inCOCA. From the data collected, the number of the verb should usage is 435,903 data from the total $6,008,860$ data. The present writers figure out the elements follow the verb should as described in the following.

$$
\begin{array}{ll}
\text { should }+\mathrm{V} & \text {...have on their victims. These } \\
& \text { justifications are premised on the } \\
& \text { notion that the state should take } \\
\text { the interests of victims into } & \text { account when determining how } \\
& \text { severely.... } \\
\text { should }+ \text { not }+\mathrm{V} \quad & \text {...time three categories of } \\
& \text { offenses in regard to which all } \\
& \text { parties should agree differential } \\
& \text { punishment should } \text { not extend. } \\
& \text { \# In those circumstances where } \\
& \text { differential.... }
\end{array}
$$

should $+\mathrm{Adv}+\mathrm{V} \quad$ \#In those circumstances where differential punishment is unwarranted, an offender should only be punished for culpable behavior within her control, and not....

should + NP \# Why, then, in the words of H.L.A. Hart, " should the accidental fact that... a harmful outcome has not occurred be a 
From the examples above, it is described that there are four types of the elements following the verbshould. The category is divided into two general types: statement and negative form. The statement are, firstly, should $+V$ (full verb or lexical verb); secondly, should $+A d v+V$ (full verb or lexical verb); thirdly, should $+N P$ (Noun Phrase) while the negative form is should + not $+V$ (full verb or lexical verb).

\section{(vii) Modal Auxiliary Verb: might}

Verb might is one of the nine of modal auxiliary verbs. This verb is the seventh frequent use in COCA. The number of the verb might usage is 300,258data from $6,008,860$ as the total number of data. The followings are the examples of the data cointaining modal auxiliary verb might and the elements follow the verb.

$$
\begin{aligned}
& \text { might }+\mathrm{Adv}+\mathrm{V} \quad \text {...unauthorized entry into a building } \\
& \text { with intent to commit a felony } \\
& \text { therein,? one might reasonably } \\
& \text { think that the intended felony, and } \\
& \text { not the unlawful entry, is the.... }
\end{aligned}
$$

There are only two types of elements following the modal auxiliary verb might, as described in the examples

\begin{tabular}{|c|c|}
\hline must $+\mathrm{V}$ & $\begin{array}{l}\text { Moore, in order to avoid the } \\
\text { "trap " of moral skepticism, } \\
\text { we must abandon the idea that causal } \\
\text { determinism is incompatible with } \\
\text { legitimate attributions of culpability } \\
\text { and.... }\end{array}$ \\
\hline ust $+A d v+V$ & $\begin{array}{l}\text { As Stephen Morse and others have } \\
\text { pointed out, the system of criminal } \\
\text { law must necessarily presuppose a } \\
\text { "compatibilist" } 71 \text { view with regard } \\
\text { to free action. }\end{array}$ \\
\hline nust + not $+V$ & $\begin{array}{l}\text {...condition punishment on whether } \\
\text { harm befalls those victims. \# The } \\
\text { importance of this point } \text { must not be } \\
\text { overlooked: while the reader may } \\
\text { not accept as legitimate the.... }\end{array}$ \\
\hline
\end{tabular}
above. The two types are both statements: firstly, might + $A d v+V$ (full verb or lexical verb) and secondly might $+V$ (full verb or lexical verb).

\section{(viii) Modal Auxiliary Verb: must}

Verb must is also one of the modal auxiliary verbs and it is the eighth frequent use in Corpus of COCA. From the data collected, the number of the verb must usage is 223,936 data from the total $6,008,860$. The present writers figure out the elements follow the verb must as described in the following.
From the examples above, it is described that there are three types of the elements following the verb. The category is divided into two general types: statement and negative form. The statements are, must $+V$ (full verb or lexical verb) and must $+A d v+V$ (full verb or lexical verb) while the negative form is $m u s t+$ $n o t+V$ (full verb or lexical verb)

\section{(ix) Modal Auxiliary Verb: shall}

Verb shall is also one of the modal auxiliary verbs and the verb shallis the lowest frequent use in COCA. From the data collected, the number of the verb shall usage is 20,372 data from the total $6,008,860$ data. The present writers figure out the elements follow the verb shall as described in the following.

shall $+\mathrm{V} \quad$... of imprisonment is to be imposed, in determining the length of the term, shall consider the factors set forth in section 3553(a) to the extent that they are applicable....

shall + not $+\mathrm{V}$ Provided further, That the limitations contained in this section for the commencement of suits shall not bar any suit against the United States brought hereunder within one....

shall $+\mathrm{Adv}+\mathrm{V} \quad$... force of history: " In running over the pages of our history, we shall scarcely find a single great event of the last seven hundred years that has not....

There are three types of element following the modal auxiliary verb shall. It is divided into two general types: statement and negative forms. The statements are, shall $+V$ (full verb or lexical verb) and shall $+A d v+V$ (full verb or lexical verb) while the negative form is shall $+n o t+V$ (full verb or lexical verb).

The following is the Picture 4 as a picture of the types of element following the nine modal auxiliary verbs found in COCA.

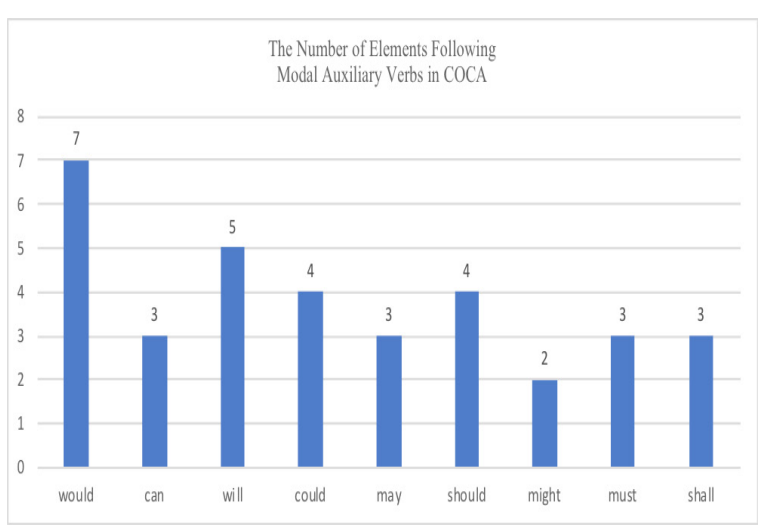

Picture 4. The Numer of Elements Following Modal Auxiliary Verbs in COCA 
Picture 4 describes that from the nine modal auxiliary verbs, the modal auxiliary verbwould has the most various element following the verb would while the modal auxiliary verb will becomes the second, could and should becomes the third, can, may, must, and shall becomes the fourth, and the modal auxiliary verb might becomes the least types of modal auxiliary verb that has elements following the verb.

\section{CONCLUSION}

After collecting, identifying, and analyzing the data, the present writers,finally, could describe two different findings. The findings from the research uses of corpusbased have shown several valuable insights. The first conclusion is the frequency and the order of the rank of modal auxiliary verbs found in the COCA has been revealed. The data describes how many times modal auxiliary verbs are used in the COCA have been exposed to these modal auxiliary verbs in various degrees.

The second conclusion is this study has revealed the elements following each of modal auxiliry verbs found in the COCA. The modal auxiliary would has the most various element following the verb and might has the least. As an addition, from the data analyzed, it is also reported that the modal auxiliary verb would is not only has various number in frequency (as the highest frequency) but also has various number in the elements follow the verb (as the highest element types).

Based on the result of the research, those are the important information on the use of modal auxiliary verbs and their structure in real language since the data are collected from corpus.

\section{REFERENCES}

Biber, D., Johansson, S., Leech, G., Conrad, S. \& Finegan, E. (1999). Longman Grammar of Spoken and Written English. Harlow: Pearson Education Limited.

Hsieh, C.L. (2005). Modal Verbs and Modal Adverbs in Chinese: An Investigation into Semantic Source. University System of Taiwan Working Papers in Linguistics 1, pp. 31-58.

Jones, C. \& Walter, D. (2015). Corpus Linguistics for Grammar. New York: Routledge .

Kennedy, G. (2002). Variation in distribution of modal verbs in the British National Corpus. In R. Reppen, S. M. Fitzmaurice, \& D. Biber, Using Corpora to Explore Linguistic Variation. Amsterdam: John Benjamin Publishing Company.

Mukundan, J., \& Khojasteh, L. (2011). Modal Auxiliary Verbs in Prescribed Malaysian English Textbooks. English Language Teaching, 4, (1), pp.79-89.

Quirk, R., Greenbaum, S., Leech, G., \& Svartvik, J. (1992). A Comprehensive Grammar of the English Language. London: Longman .

Sujatna, E. T. S. (2012). Object Complements in English. Saarbrucken: Lambert Academic Publishing.

Sujatna, E. T. S. (2013). Understanding English Syntax. Bandung: Unpad Press

Verstraete, J.-C. (2001). Subjective and objective modality: Interpersonal and ideational functions in the English modal auxiliary system. Journal of Pragmatic, 33, (10), pp. 1505-1528.

Watkins, M. (1990). Practice Your Modal Verbs. Singapore: Longman. 